\title{
PENGARUH PEMBERIAN EKSTRAK KASAR DAUN API-API (Avicennia marina) TERHADAP HISTOPATOLOGI HATI IKAN KOI (Cyprinus carpio) YANG DIINFEKSI BAKTERI Aeromonas hydrophilla
}

\author{
Sri Andayani ${ }^{\mathrm{a}}$, Heny Suprastyani ${ }^{\mathrm{a}}$, Dwi Ratih Sulistyorinie ${ }^{\mathrm{a}, *}$ \\ ${ }^{a}$ Program Studi Budidaya Perairan, Fakultas Perikanan dan Ilmu Kelautan, \\ Universitas Brawijaya, Jl Veteran Malang, Indonesia \\ *Koresponden penulis : dwiratihsr@gmail.com
}

\begin{abstract}
Abstrak
Serangan penyakit pada budidaya ikan koi seperti Aeromonas hydrophilla dapat menyebabkan kerugian ekonomi dalam budidaya. Banyak upaya yang dilakukan untuk mengobati serangan bakteri A. hydrophilla salah satunya menggunakan fitofarmaka ekstrak kasar daun api-api (Avicennia marina). Penelitian ini bertujuan untuk mengetahui pengaruh penggunaan ekstrak kasar daun api-api (A. marina) dan mengetahui dosis terbaik terhadap histopatologi hati ikan koi yang diinfeksi bakteri A. hydrophilla. Metode penelitian yang digunakan yaitu metode eksperimen dengan Rancangan Acak Lengkap (RAL). Perlakuan dalam penelitian ini adalah sebanyak 4 perlakuan dengan 3 kali ulangan. Perlakuan A (10 ppm), B (30 ppm), C (50 ppm) dan D (70 ppm). Hasil pengamatan histopatologi hati pada ikan koi diperoleh adanya kerusakan berupa kongesti, hemoragi dan nekrosis pada organ hati. Perendaman dengan ekstrak kasar daun api-api $(A$. marina) menunjukkan hasil yang berpengaruh nyata $(\mathrm{P}>0,05)$ hal ini terbukti dari semakin tinggi dosis ekstrak yang digunakan semakin rendah kerusakan pada hati ikan. Oleh karena itu, perendaman ekstrak kasar daun api-api (A. marina) mampu memberikan efek penyembuhan pada ikan koi (C. carpio) yang diinfeksi bakteri A. hydrophilla. Hasil penelitian menunjukkan bahwa hasil terendah didapatkan pada perlakuan A (10 ppm) dan hasil terbaik ada pada perlakuan D (70 ppm).
\end{abstract}

Kata kunci : Aeromonas hydrophilla, daun api-api, hati, histopatologi, ikan koi

\begin{abstract}
Bacterial disease caused by Aeromonas hydrophilla often infected common carp culture. Many efforts made to prevent infection by A. hydrophilla bacteria, one of which used phytopharmaca grey mangrove leaf crude extract. This aims of this research to determine the effect of the use of grey mangrove (A. marina) crude extract and determine the effective dose on histopathology liver of common carp was infected by bacteria A. hydrophilla. This research used experimental method with Completely Randomized Design (CRD) 4 treatments and 3 replications. These treatment were A $(10 \mathrm{ppm}), \mathrm{B}(30 \mathrm{ppm}), \mathrm{C}(50 \mathrm{ppm})$ and D $(70 \mathrm{ppm})$. Soaking with grey mangrove leaf crude extract showed a significant effect $(\mathrm{P}>0,05)$ on histophatology of liver. The results of histophatology observation of the liver showed damage in the form congestion, hamorrhage and necrosis. Soaking grey mangrove leaf crude extract at a dose that has been able to provide a care for common carp infected bacteria A. hydrophilla. The results showed that the lowest results were obtained in treatment $\mathrm{A}(10 \mathrm{ppm})$ and the best results were in treatment $\mathrm{D}(70 \mathrm{ppm}$.
\end{abstract}

Keywords: Aeromonas hydrophilla, Cyprinus carpio, grey mangrove leaf, histopathology, liver

\section{PENDAHULUAN}

Indonesia merupakan negara yang mempunyai sumber daya perikanan yang melimpah. Pemanfaatan sumberdaya perikanan sudah mengarah ke perikanan budidaya, dimana input teknologi dimasukan untuk mencapai hasil yang maksimal.
Dampak dari adanya input tersebut adalah adanya ketidakseimbangan ekosistem budidaya yang berakibat pada timbulnya penyakit pada komoditas yang dipelihara [1].

Salah satu budidaya yang saat ini menjanjikan keuntungan adalah budidaya ikan koi (Cyprinus carpio). Namun, kendala dalam budidaya ikan koi adalah adanya 
serangan penyakit[2]. Ikan koi merupakan ikan yang sangat rentan terhadap serangan penyakit. Penyakit yang menyerang ikan koi salah satunya adalah Motile Aeromonas Septicemia (MAS) yang disebabkan oleh bakteri Aeromonas hydrophilla. Bakteri A. hydrophilla dapat menyebabkan $80 \%$ kematian ikan budidaya pada berbagai stadia [3].

Upaya pengobatan yang sering dilakukan pada ikan yang terinfeksi $A$. hydrophilla yaitu dengan menggunakan obatobatan kimia. Namun, penggunaan bahan kimia cenderung tidak ramah lingkungan dan ada yang bersifat karsinogenik. Seiring dengan adanya kecenderungan yang memperhatikan masalah keamanan pangan dan lingkungan maka diharapkan adanya metode pengobatan penyakit bakterial yang bersifat aman bagi pembudidaya, ramah lingkungan dan murah melalui pemanfaatan tanaman herbal. Beberapa jenis tanaman diketahui memiliki senyawa aktif yang berfungsi sebagai anti bakteri, salah satunya adalah daun api-api (Avicennia marina) [4].

Berdasarkan masalah tersebut maka perlu dilakukan penelitian terhadap pengaruh pemberian ekstrak kasar daun api-api $(A$. marina) terhadap histopatologi hati ikan koi (C. carpio) yang diinfeksi bakteri $A$. hydrophilla yang dapat berperan sebagai alternatif penggunaan antibiotik yang lebih aman bagi lingkungan dan memiliki residu yang lebih sedikit dari pada antibiotik. Selain itu juga mengurangi resistensi ikan terhadap antibiotik yang diberikan.

Tujuan dari penelitian ini adalah untuk mengetahui ekstrak kasar daun api-api ( $A$. marina) terhadap histopatologi hati ikan koi (C. carpio) yang diinfeksi bakteri $A$. hydrophilla dan untuk mengetahui dosis terbaik pemberian ekstrak kasar daun api-api (A. marina) terhadap histopatologi hati ikan koi (C. carpio) yang diinfeksi bakteri $A$. hydrophilla.

\section{METODE PENELITIAN}

Metode yang digunakan pada penelitian ini adalah metode eksperimental yaitu dengan mengamati secara langsung pengaruh pemberian ekstrak kasar daun apiapi (A. marina) terhadap histopatologi hati ikan koi (C. carpio) yang diinfeksi bakteri $A$. hydrophilla. Parameter utama dalam penelitian ini adalah histopatologi hati ikan koi. Rancangan yang digunakan adalah Rancangan Acak Lengkap (RAL). Pada penelitian ini menggunakan 4 perlakuan, 2 kontrol dengan 3 ulangan. Perlakuan yang digunakan adalah ekstrak kasar daun api-api (A. marina) dengan dosis $10 \mathrm{ppm}, 30 \mathrm{ppm}$, $50 \mathrm{ppm}$ dan $70 \mathrm{ppm}$. Sedangkan kontrol positif dengan pemberian antibakteri chloramphenicol $30 \mathrm{ppm}$ dan kontrol negatif ikan koi hanya diinfeksi bakteri $A$. hydrophilla saja tanpa diberi perlakuan.

\section{Waktu dan Tempat}

Penelitian dilaksanakan pada bulan Desember 2018 sampai dengan Februari 2019 di Laboratorium Ilmu Teknologi Hasil Perairan Divisi Keamanan Hasil Perikanan dan Laboratorium Hidrobiologi Divisi Sumberdaya Ikan di Fakultas Perikanan dan Ilmu Kelautan Universitas Brawijaya, Malang.

\section{Alat dan Bahan}

Alat-alat yang digunakan pada penelitian ini antara lain: toples plastik 16L, toples kaca $10 \mathrm{~L}$, Akuarium ukuran 200 x 60 $\mathrm{x}$ 80, timbangan digital, aerator set, pipet volume, bola hisab, nampan, oven, penggilingan, pipet tetes, jarum ose, bunsen, tabung reaksi, lemari pendingin, botol film, gelas ukur, sprayer, mikroskop, spektrofotometer, rotary evaporator, inkubator, vortex mixer, objek glass, cover glass, seser ikan, erlenmeyer, hotplate, thermometer akuarium, $\mathrm{pH}$ meter, DO meter, tabung reaksi, rak tabung reaksi, penggaris, spatula, washing bottle, autoklaf, laminary air flow, beaker glass dan sectio set.

Bahan-bahan yang digunakan pada penelitian ini antara lain: ikan koi (C. carpio) ukuran 8-10 cm, daun api-api (A. marina), Bakteri A. hydrophilla, alumunium foil, alkohol 70\%, etanol PA, akuades, sarung tangan lateks, kertas saring, plastik wrap, masker, tissue, kapas, kertas label, nutrient agar, nutrient broth, air media, $\mathrm{BaCl}, \mathrm{H}_{2} \mathrm{SO}_{4}$ dan spirtus.

\section{Prosedur Penelitian}


Pembuatan Ekstrak Kasar Daun Api-Api (A. marina)

Proses pembuatan ekstrak kasar dimulai dengan menyiapkan daun api-api ( $A$. marina). Daun api-api didapatkan dari Desa Betoyoguci Kecamatan Manyar Kabupaten Gresik Jawa Timur sebanyak $3 \mathrm{~kg}$. Selanjutnya daun api-api tersebut dikeringkan menggunakan oven dengan suhu $<60^{\circ} \mathrm{C}$ dan didapatkan berat daun kering sebanyak 1,245 g. Daun kemudian digiling hingga menjadi serbuk, hasil penggilingan ditimbang menggunakan timbangan digital, didapatkan serbuk sebanyak $1,040 \mathrm{~g}$. Langkah selanjutnya yaitu proses maserasi. Maserasi dilakukan dengan perbandingan 1:5, serbuk daun api-api sebanyak $200 \mathrm{~g}$ dimaserasi menggunakan etanol PA 98\% sebanyak $1000 \mathrm{ml}$ dan dibungkus alumunium foil dan plastic wrap selama 2 hari (dihomogenkan setiap 7 jam). Siapkan wadah untuk penyaringan dan saring menggunakan kertas saring rangkap 2. Larutan hasil penyaringan dibungkus alumunium foil dan disimpan ditempat yang tidak terkena cahaya matahari. Selanjutnya larutan hasil penyaringan diuapkan menggunakan rotary evaporator dengan suhu $50^{\circ} \mathrm{C}$ hingga berbentuk pasta. Ekstrak hasil evaporasi diletakkan dalam botol film dan dibungkus dengan alumunium foil, selanjutnya disimpan pada lemari pendingin.

\section{Persiapan Bakteri A. Hydrophilla}

Bakteri A. hydrophilla diperoleh dari BBPBAP (Balai Besar Perikanan Budidaya Air Payau) Jepara, Jawa-Tengah. Bakteri diperoleh dengan kepadatan $9 \times 10^{8} \mathrm{sel} / \mathrm{ml}$ hasil pengukuran pada media NB (Nutrient Broth) yang sudah dicocokkan dengan larutan standar Mc Farland.

\section{Persiapan Ikan Uji}

Ikan uji yang digunakan adalah ikan koi (C. carpio) yang didapatkan dari pembudidaya ikan di daerah Blitar. Ikan yang digunakan dalam penelitian berukuran 8-10 $\mathrm{cm}$ dan bobot ikan $3,60-8,84$ g. Ikan dipelihara selama 7 hari di akuarium berukuran (200x60x80) m untuk pengadaptasian. Padat tebar ikan uji yang digunakan pada setiap akuarium sebanyak 1 ekor/2 L [5]. Masing-masing toples yang akan digunakan diisi $10 \mathrm{~L}$ air dan ikan uji sebanyak 5 ekor. Selanjutnya ikan diaklimatisasi selama 3 hari pada toples. Selama aklimatisasi ikan koi diberi pakan pelet secara adlibitum sebanyak 2 kali sehari dan dilakukan penyiponan apabila air pemeliharaan sudah kotor.

\section{Uji Lethal Dose $50 \%\left(L D_{50}\right)$}

Ekstrak kasar daun api-api (A. marina) yang didapat setelah dilakukan uji MIC adalah dosis 10 ppm, 35 ppm, 60 ppm dan 85 ppm. Pada uji $\mathrm{LD}_{50}$ menggunakan ikan koi (C. carpio) dengan ukuran 8-12 $\mathrm{cm}$ dengan jumlah 20 ekor yang dibagi menjadi 4 perlakuan sehingga setiap perlakuan terdapat 5 ekor ikan uji. Sebelum dilakukan pemberian ekstrak, ikan diadaptasikan selama 1 minggu dan diberi pakan pelet 2 kali sehari yaitu pukul 08.00 dan 15.00 WIB. Setelah itu, ikan diletakkan ke dalam toples perlakuan dan diberi ekstrak daun api-api ( $A$. marina) sesuai dengan dosis yang telah ditentukan. Selanjutnya ikan diamati selama 48 jam. Setelah 48 jam diperoleh hasil yaitu pada dosis 85 ppm ikan uji mengalami kematian sebanyak 50\%. Hal ini dikarenakan pada dosis 85 ppm kadar ekstrak terlalu tinggi, tingginya ekstrak menyebabkan toksik pada media budidaya. Sehingga dosis yang digunakan pada perlakuan penelitian adalah dosis dibawah dosis 85 ppm, yaitu 10, 30, 50 dan $70 \mathrm{ppm}$.

\section{Pelaksanaan Penelitian}

Penginfeksian Bakteri A. hydrophila pada ikan koi (C. carpio)

Penginfeksian bakteri dilakukan
dengan cara perendaman dengan memasukkan bakteri langsung pada media pemeliharaan. Penginfeksian menggunakan bakteri A. hydrophilla dengan kepadatan $1 \mathrm{x}$ $10^{7} \mathrm{sel} / \mathrm{ml}$. dengan menggunakan rumus pengenceran menurut [6] sebagai berikut:

$$
\begin{array}{ll}
\mathrm{V}_{1} \times \mathrm{N}_{1} & =\mathrm{V}_{2} \times \mathrm{N}_{2} \\
\mathrm{~V}_{1} \times 9 \times 10^{8} & =10.000 \times 10^{7} \\
\mathrm{~V}_{1} & =\frac{10.000 \times 10^{7}}{9 \times 10^{8}}
\end{array}
$$




$$
\mathrm{V}_{1} \quad=111 \mathrm{ml}
$$

Berdasarkan perhitungan diatas diketahui kebutuhan bakteri yang digunakan adalah sebanyak $111 \mathrm{ml}$.

\section{Pemberian Ekstrak Kasar A. marina}

Pemberian ekstrak kasar daun api-api (A. marina) dengan perendaman dengan cara memasukkan ekstrak kasar daun api-api ke dalam media pemeliharaan. Perendaman dilakukan selama 48 jam. Setelah itu ikan dipindah ke dalam air bersih selama 7 hari pemeliharaan. Selama pemeliharaan dilakukan pengukuran parameter penunjang yaitu $\mathrm{DO}, \mathrm{pH}$ dan suhu setiap hari pada pukul 08.00 dan 15.00 WIB.

\section{Pengambilan Jaringan Hati}

Pengambilan jaringan hati dilakukan hanya padal ekor ikan setiap perlakuan. Jaringan hati yang telah diambil dibersihkan dengan menggunakan aquades. Setelah itu dimasukkan ke dalam botol film yang berisi formalin $10 \%$. Kemudian dilakukan pembuatan preparat histopatologi.

\section{Pembuatan Preparat Histopatologi}

Adapun tahapan uji histopatologi Menurut [7] adalah sebagai berikut:

a. Tahap Fiksasi

Sampel hati diambil untuk diamati jaringannya kemudian jaringan direndam dalam larutan formalin $10 \%$ selama 24 jam.

b. Tahap Dehidrasi

Tahap dehidrasi dilakukan dengan memasukkan ke dalam botol yang berisi alkohol. alkohol yang digunakan dengan seri naik yang terdiri dari alkohol $70 \%$, alkohol $80 \%$, alkohol $96 \%$ dan alkohol absolute.

c. Tahap Clearing

Tahap clearing untuk mentransparankan dilakukan dengan mencelupkan ke dalam larutan xylol 1 selama 1 jam, xylol 2 selama 2 jam.

d. Tahap Impregnasi

Tahap impregnasi bertujuan untuk menyamakan keadaan jaringan dengan bahan pengeblokan (embedding).
Dilakukan dengan mencelupkan bahan ke paraffin cair dengan suhu $56-60^{\circ} \mathrm{C}$ selama 2 jam, kemudian dilanjutkan dengan mencelupkan kembali ke dalam paraffin cair dengan suhu $56-60^{\circ} \mathrm{C}$ selama 2 jam.

e. Tahap Embedding (Pengeblokan)

Tahapan ini bertujuan untuk memudahkan penyayatan dengan menggunakan mikrotom. Setelah penyayatan bahan yang sudah diblok selesai, langkah berikutnya adalah memasukkan hasil sayatan ke dalam waterbath (suhu $45^{\circ} \mathrm{C}$ ), kemudian pilih hasil sayatan yang terbaik dan siapkan obyek glass untuk persiapan pewarnaan HE (Haematoxylin Eosin). Kemudiaan keringkan pada oven dengan suhu $45^{\circ} \mathrm{C}$ selama 24 jam.

f. Teknik Pewarnaan Jaringan dengan Menggunakan HE (Haematoxylin Eosin)

Pewarnaan dengan menggunakan HE (Haematoxylin Eosin) dilakukan dengan beberapa tahapan yaitu deparafinisasi, hidrasi, cat utama, dehidrasi dan clearing.

g. Tahap Mounting

Preparat dilem dengan menggunakan entelen new. Kemudian ditutup dengan cover glass jangan sampai terjadi gelembung. Preparat dibiarkan dalam suhu ruangan sampai lem mengering kemudian diamati dibawah mikroskop dengan menggunakan perbesaran 400x.

\section{Parameter Penelitian}

Parameter utama dalam penelitian ini yaitu histopatologi hati ikan koi (C. carpio). Pengamatan histopalogi dilakukan bertujuan untuk melihat gambaran jaringan hati pada ikan yang diinfeksi yang diobati dengan daun api-api dan ikan tanpa perlakuan yang diinfeksi, kemudian dilakukan skoring kerusakan histopatologi hati. Menurut [8], skoring yaitu pemberian skor terhadap masing-masing parameter untuk menentukan tingkat penilaiannya pada jaringan dengan cara menghitung jumlah kerusakan dengan menghitung persentasenya. Pembacaan dimulai dari tepi kiri (sesuai dengan posisi ekor preparat) ke arah kepala kemudian turun ke bawah dan bergeser ke arah ekor kembali (gerak zig-zag). Setiap bidang lapang pandang diamati tingkat kerusakan jaringannya dengan kriteria kongesti, hemoragi dan nekrosis, kemudian 
dipersentase dengan pemberian skor dari angka 1 sampai 4. Angka 1 mempunyai tingkat persentase kerusakan jaringan $0-5 \%$, angka 2 tingkat persentase kerusakan jaringan 6-25\%, angka 3 tingkat persentase kerusakan jaringan $26-50 \%$ dan angka 4 tingkat persentase kerusakan jaringan $>50 \%$.

Sedangkan parameter penunjang pada penelitian ini adalah kelulushidupan (Survival Rate) dan parameter kualitas air (suhu, oksigen terlarut dan $\mathrm{pH}$ ). Kelulushidupan dapat dihitung dengan rumus sebagai berikut [9]:

$$
\mathrm{SR}=\frac{\mathrm{Nt}}{\mathrm{N} 0} \times 100 \%
$$

Keterangan:

$\mathrm{SR}=$ Kelulushidupan ikan (\%)

$\mathrm{Nt}=$ Jumlah ikan hidup pada akhir penelitian (ekor)

N0 $=\underset{\text { awalpenelitian (ekor) }}{\text { Jumlah }}$ ikan hidup pada

\section{Analisis Data}

Data yang diperoleh dari hasil penelitian dilakukan analisis secara statistika dengan analisis keragaman atau uji $\mathrm{F}$ (ANOVA) sesuai dengan rancangan yang digunakan.Tujuan analisis keragaman atau uji $F$ adalah untuk mengetahui pengaruh perlakuan terhadap respon parameter yang diukur. Apabila hasil uji $\mathrm{F}$ menunjukkan berbeda nyata atau berbeda sangat nyata maka dilakukan uji BNT (Beda Nyata Terkecil) untuk membedakan antara dua perlakuan terbaik. Untuk mengetahui hubungan antara perlakuan dengan jumlah kerusakan jaringan hati maka dilakukan uji polynomial orthogonal.

\section{HASIL DAN PEMBAHASAN}

\section{Hasil Uji Histopatologi}

Gambaran Hati Ikan yang Diinfeksi Bakteri A.hydrophilla dan Normal

Pada Gambar 1 (A) dapat dilihat jaringan hati ikan sehat menunjukkan tidak adanya kerusakan. Sedangkan pada Gambar 1 (B) yaitu jaringan hati yang diinfeksi bakteri dan tanpa pemberian ekstrak daun api-api (A. marina) terlihat banyak terjadi kerusakan. Kerusakan yang terjadi diantaranya Kongesti Hemoragi dan Nekrosis.
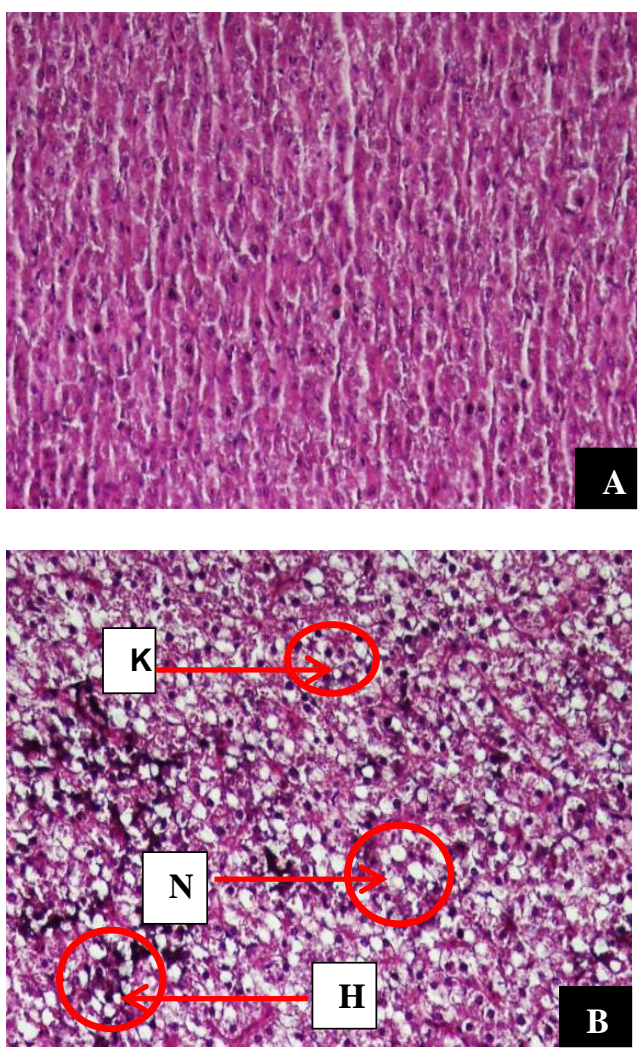

Gambar 1. Gambar Histopatologi Hati, (A) Histopatologi Hati Ikan Sehat, (B) Histopatologi Hati yang diinfeksi $A$. hydrophilla dan tanpa pemberian ekstrak kasar A. marina, (K) Kongesti (H) Hemoragi (N) Nekrosis. Pengaamatan dengan menggunakan perbesaran 400x dengan Pewarnaan HE.

\section{Gambaran Histopatologi Hati pada Sampel Perlakuan}

Pengamatan Histopatologi digunakan untuk melihat perubahan patologi pada perendaman ikan koi (C. carpio) dengan ekstrak daun api-api yang diinfeksi bakteri $A$. hydrophilla dengan perlakuan dosis yang berbeda. Perlakuan yang digunakan pada saat penelitian terdiri dari 4 macam diantaranya perlakuan A dengan dosis sebesar $10 \mathrm{ppm}$, perlakuan B dengan dosis sebesar $30 \mathrm{ppm}$, perlakuan $\mathrm{C}$ dengan dosis sebesar $50 \mathrm{ppm}$ dan yang terakhir perlakuan D dengan dosis sebesar $70 \mathrm{ppm}$. Pemeliharaan dilakukan selama 7 hari. Gambar jaringan hati pada sampel perlakuan dapat dilihat pada Gambar 2. 

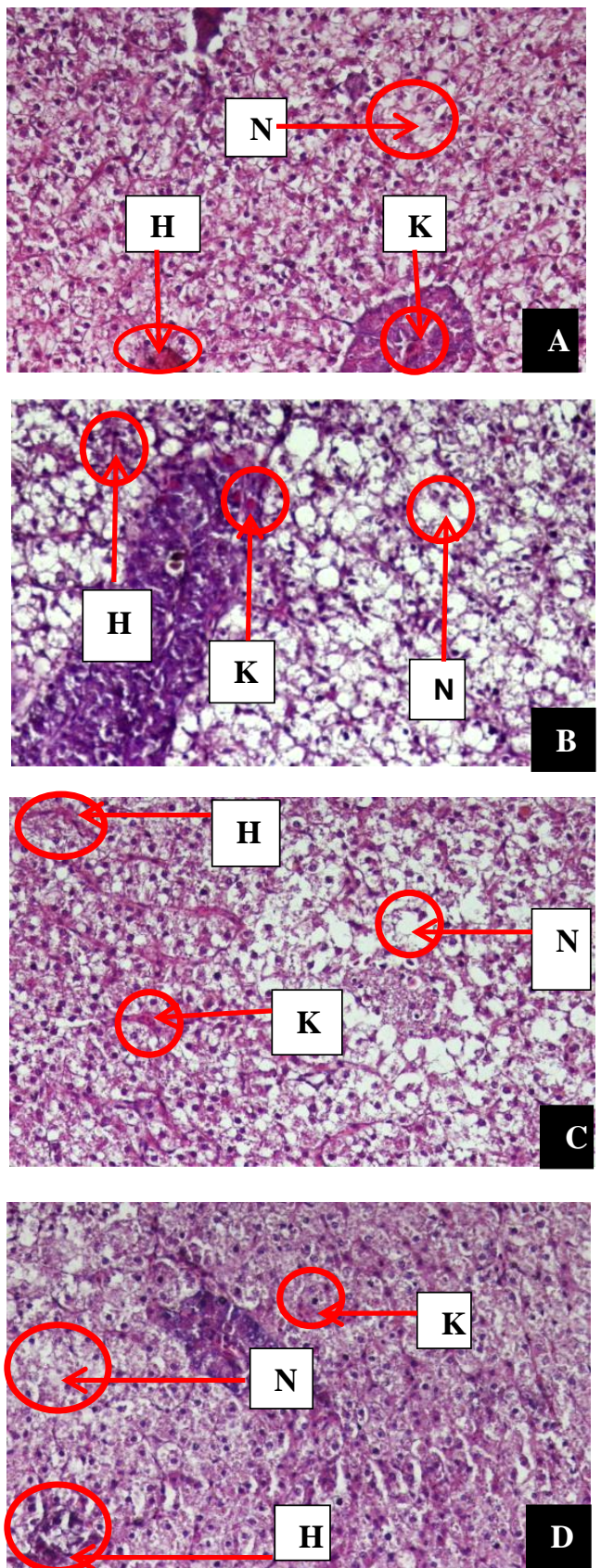

Gambar 2. Gambar Histopatologi Hati, (A) Dosis 10 ppm, (B) Dosis 30 ppm,(C) Dosis 50 ppm, (D) Dosis 70 ppm, (K) Kongesti (H) Hemoragi (N) Nekrosis. Pengamatan dengan menggunakan perbesaran 400x dengan pewarnaan HE.

Adapun analisis data kerusakan pada histopatologi jaringan hati yang diinfeksi bakteri A. hydrophilla yang direndam dalam ekstrak kasar daun api-api adalah sebagai berikut:

a. Kongesti

Menurut [10], kongesti merupakan keadaan terjadinya penumpukan sel-sel darah merah yang sangat padat dalam pembuluh darah yang menunjukkan kondisi tidak normal pada hati ikan. Menurut [11], kerusakan kongesti pada hati terjadi akibat adanya pembengkakan sel sehingga sinusoid menyempit. Sinusoid merupakan suatu rongga yang terdapat pada jaringan hati yang memungkinkan terjadinya pertukaran nutrisi dan zat lainnya antara darah dan hepatosit. Apabila sinusoid menyempit, maka darah akan terbendung di dalam jaringan hati sehingga proses pertukaran nutrisi maupun zat lain akan terganggu. Menurut [12], bakteri A. hydrophilla salah satu bakteri gram negatif yang dapat menyebabkan terjadinya kongesti pada hati. Adapun hasil rata-rata pada kongesti disajikan pada Tabel 1.

Tabel 1. Hasil Rata-Rata Kerusakan Kongesti

\begin{tabular}{cc}
\hline Perlakuan & Rerata \\
\hline A (10 ppm) & $1,53^{\mathrm{a}}$ \\
B (30 ppm) & $1,33^{\mathrm{a}}$ \\
C (50 ppm) & $1,27^{\mathrm{ab}}$ \\
D (70 ppm) & $1,13^{\mathrm{b}}$ \\
\hline
\end{tabular}

Berdasarkan analisis varian (ANOVA), perlakuan pemberian ekstrak kasar daun apiapi memberikan hasil berpengaruh terhadap kerusakan kongesti jaringan hati. Hasil ratarata kerusakan kongesti tertinggi adalah perlakuan A dengan dosis 10 ppm, sedangkan rata-rata kerusakan kongesti terendah adalah perlakuan D dengan dosis 70 ppm. Adapun Grafik hubungan dosis ekstrak daun api-api dengan nilai skoring kongesti dapat dilihat pada Gambar 3.

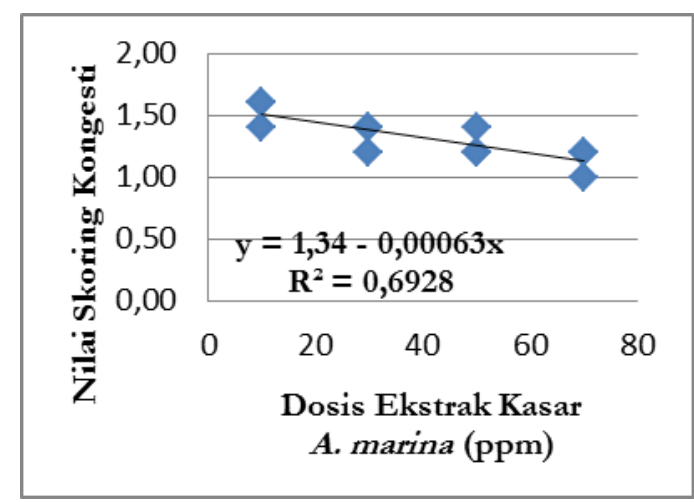

Gambar 3. Grafik Hubungan antara Dosis Ekstrak Kasar A. marina dengan Nilai Skoring Kongesti.

Pada Gambar 3 didapatkan persamaan $\mathrm{y}=1,34-0,00063 \mathrm{x}$ dan memiliki nilai 
koefisien determinasi yakni 0,6928 menunjukkan bahwa dosis yang digunakan berpengaruh terhadap presentase sel hati yang mengalami kongesti sebesar 69,28\%. Selain itu, juga dapat diketahui hubungan antara dosis ekstrak kasar daun api-api dengan sel hati yang mengalami kongesti berbanding terbalik, apabila semakin tinggi dosis maka nilai skoring kongesti semakin rendah. Menurut [13], penghambatan atau pembasmian bakteri oleh bahan antibakteri dapat dipengaruhi oleh konsentrasi atau intensitas zat antibakteri, semakin tinggi konsentrasi zat antibakteri yang diaplikasikan dalam suatu waktu tertentu maka semakin cepat pula sel-sel bakteri akan terbunuh tentunya sampai suatu batas tertentu.

\section{b. Hemoragi}

Menurut [14], hemoragi merupakan salah satu kerusakan hati tingkat sedang. Hemoragi ini terjadi bila kongesti sudah sangat parah, maka pembuluh darah akan pecah dan darah berada pada tempat yang tidak semestinya (pendarahan). Hemoragi mengindikasikan keluarnya darah dari pembuluh darah, baik keluar tubuh maupun ke dalam jaringan tubuh. Bila perdarahan meluas akan terjadi purpura dan eritrosit terlihat di luar pembuluh darah. Menurut [15], hemoragi dapat disebabkan oleh kerusakan pembuluh darah akibat agen infeksi yang beredar di pembuluh darah. Adapun hasil rata-rata pada kerusakan kongesti disajikan pada Tabel 2.

Tabel 2. Hasil Rata-Rata Kerusakan Hemoragi

\begin{tabular}{cc}
\hline Perlakuan & Rerata \\
\hline A (10 ppm) & $1,93^{\mathrm{a}}$ \\
B (30 ppm) & $1,60^{\mathrm{b}}$ \\
C (50 ppm) & $1,47^{\mathrm{bc}}$ \\
D (70 ppm) & $1,33^{\mathrm{c}}$ \\
\hline
\end{tabular}

Berdasarkan analisis varian (ANOVA), perlakuan pemberian ekstrak kasar daun apiapi memberikan hasil berpengaruh terhadap kerusakan hemoragi jaringan hati. Hasil ratarata kerusakan hemoragi tertinggi adalah perlakuan A dengan dosis $10 \mathrm{ppm}$, sedangkan rata-rata kerusakan hemoragi terendah adalah perlakuan $\mathrm{D}$ dengan dosis 70 ppm. Adapun Grafik hubungan dosis ekstrak daun api-api dengan nilai skoring hemoragi disajikan pada Gambar 4.

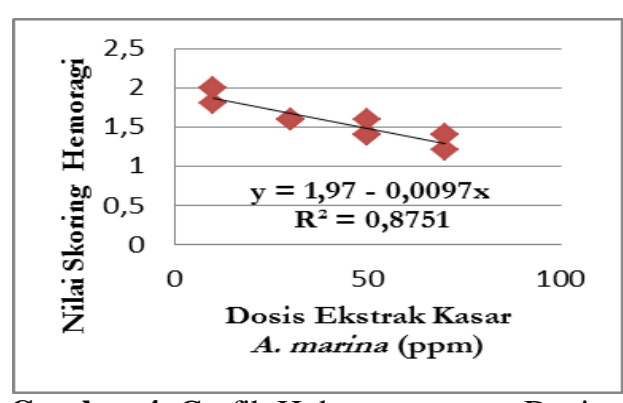

Gambar 4. Grafik Hubungan antara Dosis Ekstrak Kasar A. marina dengan Nilai Skoring Hemoragi

Pada Gambar 4 didapatkan persamaan $\mathrm{y}=1,97-0,0097 \mathrm{x}$ dan memiliki nilai koefisien determinasi yakni 0,8751 menunjukkan bahwa dosis yang digunakan berpengaruh terhadap presentase sel hati yang mengalami Hemoragi sebesar 87,51\%. Selain itu, juga dapat diketahui hubungan antara dosis ekstrak kasar daun api-api dengan sel hati yang mengalami Hemoragi berbanding terbalik, apabila semakin tinggi dosis maka nilai skoring Hemoragi semakin rendah. Menurut [16], semakin tinggi konsentrasi suatu bahan antibakteri maka semakin tinggi kandungan senyawa aktif yang berfungsi sebagai antibakteri. Sehingga kemampuan suatu bahan untuk membunuh bakteri semakin besar.

\section{c. Nekrosis}

Menurut [17], nekrosis menggambarkan keadaan terjadinya penurunan aktivitas jaringan yang ditandai dengan hilangnya beberapa bagian sel satu demi satu dari satu jaringan sehingga dalam waktu yang tidak lama akan mengalami kematian. Nekrosis biasanya disebabkan karena stimulus (perubahan lingkungan) yang bersifat patologis (penyakit). Kerusakan pada hati ikan seperti nekrosis diduga timbul karena bakteri sudah berkembang di dalam hati. Nekrosis pada sel hati disebabkan oleh aktivitas sitolisis (peristiwa pecahnya sel) yang menyebabkan pengkerutan atau pengecilan ukuran nucleus secara menyeluruh. Adapun hasil rata-rata pada kerusakan kongesti disajikan pada Tabel 3. 
Tabel 3. Hasil Rata-Rata Kerusakan Nekrosis

\begin{tabular}{cc}
\hline Perlakuan & Rerata \\
\hline A (10 ppm) & $1,93^{\mathrm{a}}$ \\
B (30 ppm) & $1,47^{\mathrm{b}}$ \\
C (50 ppm) & $1,33^{\mathrm{bc}}$ \\
D (70 ppm) & $1,00^{\mathrm{c}}$ \\
\hline
\end{tabular}

Berdasarkan analisis varian (ANOVA), perlakuan pemberian ekstrak kasar daun apiapi memberikan hasil berpengaruh terhadap kerusakan nekrosis jaringan hati. Hasil ratarata kerusakan nekrosis tertinggi adalah perlakuan A dengan dosis $10 \mathrm{ppm}$, sedangkan rata-rata kerusakan nekrosis terendah adalah perlakuan D dengan dosis 70 ppm. Grafik hubungan dosis ekstrak daun api-api dengan nilai skoring nekrosis dapat dilihat pada Gambar 5.

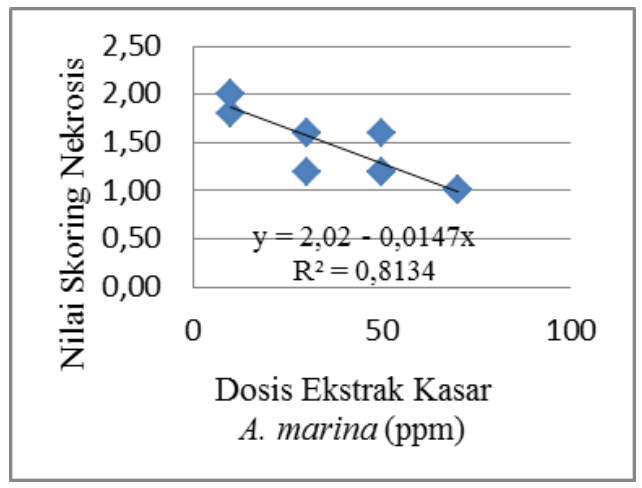

Gambar 5. Grafik Hubungan antara Dosis Ekstrak Kasar A. marina dengan Nilai Skoring Nekrosis.

Pada Gambar 5 didapatkan persamaan $\mathrm{y}=2,02-0,0147 \mathrm{x}$ dan memiliki nilai koefisien determinasi yakni 0,8134 menunjukkan bahwa dosis yang digunakan berpengaruh terhadap presentase sel hati yang mengalami nekrosis sebesar 81,34\%. Selain itu, juga dapat diketahui hubungan antara dosis ekstrak kasar daun api-api dengan sel hati yang mengalami nekrosis berbanding terbalik, apabila semakin tinggi dosis maka nilai skoring nekrosis semakin rendah.

Hasil uji fitokimia daun A. marina mengandung senyawa flavonoid, alkaloid, tanin, triterpenoid dan saponin. Menurut [18], mekanisme kerja flavonoid sebagai antibakteri yaitu menghambat pertumbuhan dan metabolisme bakteri dengan cara merusak membran sitoplasma dan mendenaturasi protein sel bakteri. Senyawa flavonoid dapat merusak membran sitoplasma yang dapat menyebabkan bocornya metabolit penting dan menginaktifkan sistem enzim bakteri. Kerusakan ini memungkinkan nukleotida dan asam amino merembes keluar dan mencegah masuknya bahan-bahan aktif ke dalam sel sehingga dapat menyebabkan kematian bakteri. Pada perusakan membran sitoplasma, ion $\mathrm{H}+$ dari senyawa fenol dan turunannya (flavonoid) akan menyerang gugus polar (gugus fosfat) sehingga molekul fosfolipida akan terurai menjadi gliserol, asam karboksilat dan asam fosfat. Hal ini mengakibatkan fosfolipida tidak mampu mempertahankan bentuk membran sitoplasma akibatnya membran sitoplasma akan bocor dan bakteri akan mengalami hambatan pertumbuhan dan bahkan kematian. Bakteri yang mengalami kematian akan di fagositosis oleh makrofag. Menurut [19], keberadaan antibakteri menjadi faktor penting melalui mekanismenya terhadap bakteri. Tanin memiliki aktifitas antibakteri yang berhubungan dengan kemampuannya untuk menginaktifkan enzim dan menggangu transport protein pada pada lapisan dalam sel. Tanin juga mempunyai target pada polipeptida dinding sel sehingga pembentukan dinding sel menjadi kurang sempurna. Hal ini menyebabkan sel bakteri menjadi lisis karena tekanan osmotik maupun fisik sehingga sel bakteri akan mati.

Gejala Klinis pada Ikan Koi (C. carpio) yang Diinfeksi Bakteri A. Hydrophilla

Berdasarkan hasil penelitian didapatkan hasil bahwa pada saat ikan dilakukan perendaman ke dalam toples yang berisi bakteri, ikan terlihat menyendiri di dasar toples dan berenang tidak beraturan. Ikan mengeluarkan lendir yang berlebihan pada permukaan tubuhnya, perut membesar, insang memucat dan sisik mulai mengelupas seperti yang disajikan pada Gambar 6 . 

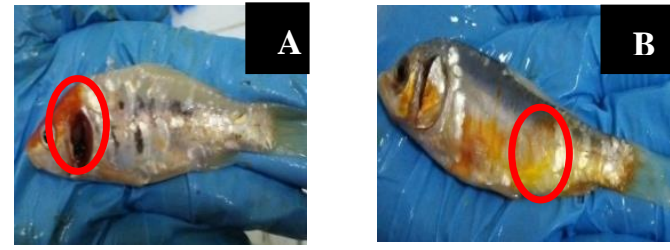

Gambar 6. Gejala klinis ikan koi (C. carpio) yang diinfeksiA. hydrophilla, (A) Insang Memucat dan (B) Sisik Mengelupas

Menurut [20], ikan yang terserang $A$. hydrophilla menunjukkan tanda-tanda diantaranya kemampuan berenang ikan menjadi lemah, nafasnya megap-megap dan sering muncul di permukaan, kurangnya nafsu makan, warna insang pucat dan rusak, warna tubuh ikan berubah menjadi gelap, kulit ikan mengeluarkan banyak lendir yang diikuti oleh pendarahan yang selanjutnya akan menjadi borok. Untuk melindungi tubuh dari infeksi bakteri, ikan akan mengeluarkan lendir terus-menerus sehingga mengakibatkan metabolisme tubuh meningkat dan pemakaian energi lebih banyak. Akibatnya ikan menjadi cepat lemah dan mudah stres. Keadaan tersebut mempermudah bakteri untuk masuk dan menginfeksi ikan.

Menurut [21], pada beberapa jenis ikan tawar sering ditemukan tanda klinis seperti pembengkakan pada perut dan berisi cairan yang diikuti dengan kematian. Infeksi $A$. hydrophila menyebabkan penyakit dengan gejala klinis seperti sisik lepas dan rontoknya sirip-sirip ikan yang terinfeksi.

\section{Parameter Kualitas Air}

Air merupakan media tempat hidup ikan selama pemeliharaan. Ikan sangat mudah terserang patogen pada lingkungan yang kurang baik. Dalam hal ini yang sangat mempengaruhi adalah kualitas air. Kualitas air merupakan faktor yang harus diperhatikan dalam pemeliharaan ikan. Ikan akan tumbuh optimal apabila parameter kualitas air di tempat hidupnya sesuai dengan kisaran toleransi yang dapat diterima oleh ikan tersebut. Pada saat penelitian, dilakukan pengukuran kualitas air yang meliputi suhu, $\mathrm{pH}$ dan oksigen terlarut (DO). Adapun hasil kisaran pengukuran kualitas air selama penelitian dapat dilihat pada Tabel 4 .
Tabel 4. Kisaran Parameter Kualitas Air

\begin{tabular}{cccc}
\hline No. & $\begin{array}{c}\text { Kualitas } \\
\text { Air }\end{array}$ & $\begin{array}{c}\text { Kisaran } \\
\text { Kualitas Air }\end{array}$ & Referensi \\
\hline 1 & $\begin{array}{l}\text { DO } \\
\text { (ppm) }\end{array}$ & $5,70-10,90$ & $>5[22]$ \\
2 & Suhu $\left({ }^{0} \mathrm{C}\right)$ & $24,50-28,70$ & $\begin{array}{l}20-30 \\
{[22]}\end{array}$ \\
3 & \multirow{2}{*}{ Ph } & $6,26-8,50$ & $\begin{array}{l}6,50-8,50 \\
{[22]}\end{array}$ \\
\hline
\end{tabular}

Kelulushidupan Ikan Koi (C. carpio)

Pada hasil penelitian diperoleh hasil kisaran kelulushidupan ikan koi (C. carpio) yaitu $60 \%$ sampai dengan $100 \%$. Terjadinya kematian pada ikan koi (C. carpio) yang diinfeksi A. hydrophilla disebabkan karena bakteri A. hydrophilla merupakan bakteri patogen dan dapat menyebabkan kematian pada ikan. Menurut [23], A. hydrophilla termasuk ke dalam kelopok bakteri patogen dengan virulensi yang tinggi. Tingkat virulensi bakteri tersebut ditentukan oleh kemampuan bakteri menghasilkan enzim dan toksin tertentu yang berperan dalam proses invasi dan infeksi.

\section{KESIMPULAN DAN SARAN}

\section{Kesimpulan}

Berdasarkan hasil penelitian, maka dapat disimpulkan sebagai berikut:

- Pemberian ekstrak kasar daun api-api (A. marina) dengan dosis yang berbeda berpengaruh terhadap histopatologi hati ikan koi (C. carpio) yang diinfeksi bakteri A. hydrophilla.

- Dosis terbaik pemberian ekstrak kasar daun api-api (A. marina) pada penelitian yaitu pada perlakuan D dengan dosis 70 ppm.

\section{Saran}

Berdasarkan hasil penelitian tentang pengaruh pemberian ekstrak kasar daun apiapi (A. marina) terhadap histopatologi hati ikan koi (C. carpio) yang diinfeksi bakteri $A$. hydrophilla

diperoleh hasil perlakuan terbaik dengan dosis 70 ppm, namun belum didapatkan dosis optimal. Oleh sebab itu, perlu dilakukan penelitian dengan dosis yang lebih tinggi dan 
penelitian lanjutan untuk mengetahui dosis yang optimal.

\section{DAFTAR PUSTAKA}

[1] Sukarni, Maftuch, dan H. Nursyam. "Kajian Penggunaan Ciprofloxacin terhadap Histologi Insang dan Hati Ikan Botia (Botia macracanthus, Bleeker) yang Diinfeksi Bakteri Aeromonas hydrophila." J. Exp. Life Sc., vol. 2, no. 1, hal 6-12, 2012.

[2] Nurjannah, R. D. D., S. B. Prayitno dan S. Sarjito. "Pengaruh ekstrak daun sirsak (Annona muricuta) terhadap profil darah dan kelulushidupan ikan mas (Cyprinus carpio) yang diinfeksi bakteri A. hydrophila." Journal of Aquaculture Management and Technology., vol. 2, no. 4, hal 1-12, 2013.

[3] Samsundari, S. "Pengujian ekstrak temulawak dan kunyit terhadap resistensi bakteri Aeromonas hydrophila yang menyerang ikan mas (C. carpio)." Gamma., vol. 1, no. 2, hal. 71-83, 2012.

[4] Karmila, U., S. Karina dan C. Yulvizar. "Ekstrak kunyit Curcuma domestica sebagai anti bakteri Aeromonas hydrophila pada ikan patin Pangasius sp." Jurnal Ilmiah Mahasiswa Perikanan dan Kelautan Unsyiah., vol. 2, no. 10, hal. 150-157, 2017.

[5] Anggraini, D., F. H. Taqwa dan Yulisman. "Mortalitas benih ikan koi (Cyprinus carpio) pada ketinggian dasar media gabus ampas tebu dan lama waktu pengangkutan yang berbeda." JPK., vol. 19, no. 1. hal. 7889, 2017.

[6] Lukistyowati, I dan Kurniasih. 2011. "Kelangsungan hidup ikan mas (Cyprinus carpio L.) yang diberi pakan ekstrak bawang putih (Allium sativum) dan di infeksi Aeromonas hydrophila." Jurnal Perikanan dan Ilmu Kelautan., vol. 16, no. 1, hal. 144-160, 2011.
[7] Kahfi, K. E., K. Fariestha, H. Suprastyani. "Histopatologi hati dan ginjal ikan lele dumbo (C. gariepinus) yang diberi pakan simplisia kulit buah manggis (Garcinia mangostana L)." Jurnal Perikanan dan Ilmu Kelautan Riau., vol 1, no. 1, hal. 1-11, 2016.

[8] Izzah, N., S. Arsad, A. W. Ekawati. "Pengaruh Penambahan Probiotik dan Minyak Ikan Pada Pakan Terhadap Histopatologi Lambung Ikan Sidat (Anguilla sp.)." Journal of Fisheries and Marine Research., vol. 3, no. 1, hal. 81-85, 2019.

[9] Kusrini, E., S. Cindelaras dan A. B. Prasetio. "Pengembangan budidaya ikan hias koi (C. carpio) lokal di balai penelitian dan pengembangan budidaya ikan hias Depok." Media Akuakultur., vol. 10, no. 2, hal. 71-78, 2015.

[10] Aminah, S. B. Prayitno dan Sarjito. "Pengaruh perendaman ekstrak daun ketapang (Terminalia cattapa) terhadap kelulushidupan dan histologi hati ikan mas (Cyprinus carpio) yang diinfeksi bakteri Aeromonas hydrophila." Journal of Aquacultur Management And Technology., vol. 3, no. 4, hal. 118-125, 2014.

[11] Nurjannah, R. D. D., S. B. Prayitno dan S. Sarjito. "Pengaruh ekstrak daun sirsak (Annona muricuta) terhadap pofik darah dan kelulushidupan ikan mas (Cyprinus carpio) yang diinfeksi bakteri A. hydrophila." Journal of Aquaculture Management and Technology., vol. 2, no. 4, hal. 1-12, 2013.

[12] Yuasa, K. N., M. B. Panigoro dan Kholidin. "Panduan Diagnosa Penyakit Ikan Budidaya Air Tawar : Teknik Diagnosa Penyakit Ikan Budidaya Air Tawar di Indonesia." International Coorperation Agency. 75 hlm, 2003.

[13] Handayani, N., S. Wahyuono, T. Hertiani dan R. Murwanti. "Uji aktivitas fagositosis makrofag ekstrak 
etanol daun suji (Dracaena angustifolia) secara in vitro." Pharmacy Medical Journal., vol. 1, no. 1, hal. 26-32, 2018.

[14] Jamin dan Erlangga. "Pengaruh insektisida golongan organofosfat terhadap benih ikan nila gift (Oreochromis niloticus, Bleeker): analisis histologi hati dan insang." Acta Aquatica., vol. 3, no. 2, hal. 4653, 2016.

[15] Salikin, R. Q., Sarjito dan S. B. Prayitno. "Pengaruh perendaman ekstraks daun binahong (Anredera cordifolia) terhadap mortalitas dan histologi hati ikan mas (Cyprinus carpio) yang diinfeksi bakteri Aeromonas caviae." Journal of Aquacultur Management and Technology., vol. 3, no. 3, hal. 43-50, 2014.

[16] Roslizawaty, N., Y. Ramadani, Fakhrurrazi dan Herrialfian. "Aktivitas antibacterial ekstrak etanol dan rebusan sarang semut (Myrmecodia sp.) terhadap bakteri Escherichia coli." Jurnal Medika Veterinaria., vol. 7, no. 2, hal. 91-94, 2013.

[17] Mandia, S., N. Marusin dan P. Santoso. "Analisis histologis ginjal ikan asang (Osteochilus hasseltii) di danau Maninjau dan Singkarak, Sumatera Barat." Jurnal Biologi Universitas Airlangga., vol. 2, no. 3, hal. 194-200, 2013.

[18] Setiawan, M. H., S. Mursiti dan E. Kusumo. "Aisolasi dan uji daya antimikroba ekstrak kulit nanas (Ananas comous L. Merr)." Jurnal MIPA., vol. 39, no. 2, hal. 128-134, 2016.

[19] Ngajow, M., J. Abidjulu dan V. S. Kamu. "Pengaruh antibakteri ekstrak kulit batang Matoa ( $P$. pinnata) terhadap bakteri Stapylococcus aureus secara in vitro." Jurnal MIPA Unsrat Online., vol. 2, no. 2, hal. 128-132, 2013.
[20] Khaerani, L, R., S. B. Prayitno dan A. H. C. Haditomo. "Pengaruh perendaman ekstrak blimbing wuluh (Averrhoa bilimbi L.) untuk mengobati infeksi Aeromonas hydrophila pada ikan mas (C.carpio)." Journal of Aquaculture Management and Technology., vol. 7, no. 1, hal. 99-106, 2018.

[21] Mangunwardoyo, W., M. R. Ismayasari dan E. Riani. "Uji patogentias dan virulensi Aeromonas hydrophila Stanier pada ikan nila (Oreochromis niloticus Lin.) melalui postulat koch." Jurnal Riset Akakultur., vol. 5, no. 2, hal. 245-255, 2010.

[22] Solichin, A., N. Widyorini dan D. S. M. Wijayanto. "Pengaruh ekstrak bawang putih (Allium sativum) dengan dosis yang berbeda terhadap lepasnya suckers kutu ikan (Argulus sp.) pada ikan koi (Cyprinus carpio)." Journal of Management of Aquatic Resources., vol. 2, no. 2, hal. 46-53, 2013.

[23] Yu, H. B., P. S. Rao, H. C. Lee, S. Vilches, S. Merino, J. M. Tomas and K. Y. Leung. "A type III secretion system is required for Aeromonas hydrophila AH-1 pathogenesis." Infection and Immunity., vol. 72, no. 3, hal. 1248-1256, 2004. 